\title{
Brain drain and human capital formation in developing countries: winners and losers
}

M. Beine, F. Docquier and H. Rapoport

Discussion Paper 2006-23

\section{Département des Sciences Économiques de l'Université catholique de Louvain}




\title{
Brain drain and human capital formation in developing countries: winners and losers.*
}

\author{
Michel Beine ${ }^{a}$, Fréderic Docquier ${ }^{b}$ and Hillel Rapoport ${ }^{c}$ \\ ${ }^{a}$ University of Luxembourg and Université Libre de Bruxelles \\ ${ }^{b}$ FNRS and IRES, Université Catholique de Louvain, and IZA, Bonn \\ ${ }^{c}$ Department of Economics, Bar-Ilan University, and CADRE, Université de Lille II
}

Revised version - May 2006

\begin{abstract}
${ }^{*}$ A previous version of this paper received the 2003 Milken Institute Award for Distinguished Economic Research (see Beine et al., 2003). Remarks and suggestions from two anonymous referees were very helpful. We thank for their comments Andrea Bassanini, John Baude, François Bourguignon, Serge Coulombe, José-Antonio Gonzales, Hubert Jayet, David McKenzie, Abdul Noury, Sergio Perelman, Pierre Pestieau, Maurice Schiff, Thomas Piketti, and seminar and conference participants for their comments. The usual disclaimer applies. Corresponding author: Frédéric Docquier, Université Catholique de Louvain, 3 Place Montesquieu, B-1348 Louvain-La-Neuve, Belgium. Email: docquier@ires.ucl.ac.be.
\end{abstract}




\begin{abstract}
The brain drain has long been viewed as a serious constraint on poor countries development. However, recent theoretical literature suggests that emigration prospects can raise the expected return to human capital and foster investment in education at home. This paper takes advantage of a new dataset on emigration rates by education level (Docquier and Marfouk, 2006) to examine the impact of brain drain migration on human capital formation in developing countries. We find evidence of a positive effect of skilled migration prospects on gross human capital levels in a cross-section of 127 developing countries. For each country we then estimate the net effect of the brain drain using counterfactual simulations. We find that countries combining relatively low levels of human capital and low skilled emigration rates are likely to experience a net gain, and conversely. There appears to be more losers than winners, and in addition the former tend to lose relatively more than what the latter gain. At an aggregate level however, and given that the largest developing countries are all among the winners, brain drain migration may be seen not only as increasing the number of skilled workers worldwide but also the number of such workers living in developing countries.
\end{abstract}

JEL Classification: F22, J24, O15.

Keywords: Brain drain, skilled migration, human capital formation, immigration policy, developing countries. 


\section{Introduction}

The term "brain drain" designates the international transfer of resources in the form of human capital and mainly applies to the migration of relatively highly educated individuals from developing to developed countries. ${ }^{1}$ Recent comparative data reveal that by 2000 there were 20 millions highly skilled immigrants (i.e., foreign-born workers with tertiary education level) living in the OECD member countries, a $70 \%$ increase in ten years against only a $30 \%$ increase for unskilled immigrants (Docquier and Marfouk, 2006). Moreover, the vast majority of these highly-skilled immigrants come from developing countries and now represent more than a third of total immigration to the OECD. The causes of this growing brain drain are well known. On the supply-side, the globalization of the world economy has strengthened the tendency for human capital to agglomerate where it is already abundant and contributed to increase positive self-selection among international migrants. And on the demand side, starting with Australia and Canada in the 1980s, host countries have gradually introduced quality-selective immigration policies and are now engaged in what appears as an international competition to attract global talent (ILO, 2006).

The consequences for source countries, on the other hand, are less obvious. Early contributions (Grubel and Scott, 1966, Bhagwati and Hamada, 1974, McCullock and Jellen, 1977) identified a range of positive feedback effects (e.g., remittances, return migration with additional skills acquired abroad, creation of scientific and business networks) but concluded that the welfare of those left behind would fall if the migrants' contribution to the economy were greater than their marginal product.

\footnotetext{
${ }^{1}$ In the non-academic literature, the term is generally used in a narrower sense, and relates more specifically to the migration of engineers, physicians, scientists or other very highly skilled professionals with university training.
} 
Since this would seem to be the case when the social return to education exceeds its private return, and given the fact that education is often at least partly publicly financed, it was widely recognized until recently that the brain drain was detrimental to the migrants' source countries. ${ }^{2}$ Typical of this view is the following citation from a classical textbook in development economics: "the irony of international migration today is that ... many of the people who migrate legally from poor to richer lands are the very ones that Third World countries can least afford to lose: the highly educated and skilled. Since the great majority of these migrants move on a permanent basis, this perverse brain drain not only represents a loss of valuable human resources but could prove to be a serious constraint on the future economic progress of Third World nations" (Todaro and Smith, 2006: 76).

In contrast, a series of recent papers (Mountford, 1997, Vidal, 1998, Beine et al., 2001) suggested instead that in a context of probabilistic migration, brain drain migration may ultimately contribute to human capital formation in the sending countries. The essence of the argument is that since the return to education is higher abroad, migration prospects can raise the expected return to human capital and induce more people to invest in education at home. Under certain theoretical conditions explored in these models, this incentive effect (or brain gain) can dominate that of actual emigration, in which case there is a net gain for the source country. Using a slightly different perspective, Stark et al. (1997) also elaborated on the possibility of a brain gain associated with a brain drain in a context of imperfect information with return migration. ${ }^{3}$

\footnotetext{
${ }^{2}$ The first papers investigating the effects of the brain drain in an endogenous growth framework also emphasized its negative impact. See Miyagiwa (1991), Haque and Kim (1995) or Wong and Yip (1999).

${ }^{3}$ McCormick and Wahba (2000) also obtain the result that more highly-skilled migration may benefit those left behind, but in a trade-theoretic model where migration, remittances and domestic
} 
In the absence of reliable comparative data on international migration by skill level, however, the debate on the consequences of the brain drain for developing countries has remained purely theoretical. ${ }^{4}$ This paper takes advantage of a recent dataset on emigration rates by education levels (Docquier and Marfouk, 2006) to empirically investigates how the positive and negative effects of the brain drain just described balance out. We first estimate the effect of skilled migration prospects on gross (or pre-migration, or ex-ante) human capital levels. We find that doubling the emigration rate of the highly skilled induces a $5 \%$ increase in gross human capital formation among the native population (residents and emigrants together). The coefficient is very stable across specifications and estimation methods. For each country of the sample we then use counterfactual simulations to estimate the total effect of the brain drain on human capital formation (i.e., once skilled emigration is netted out). We find that most countries combining low levels of human capital and low migration rates of skilled workers end up with an overall positive effect. In contrast, the brain drain appears to have negative effects in countries where the migration rate of the highly educated is above $20 \%$ and/or where the proportion of people with higher education is above $5 \%$. There appears to be more losers than winners, and in addition the former tend to lose relatively more than what the latter gain. At an aggregate level however, and given that the largest developing countries are all among the winners, brain drain migration may be seen not only as increasing the number of skilled workers worldwide but also the number of such workers living in developing

\footnotetext{
labor-market outcomes are jointly determined and multiple equilibria arise, with the high-migration equilibrium pareto-dominating the low-migration equilibrium. See Commander et al. (2004) and Docquier and Rapoport (2004) for recent surveys of this literature.

${ }^{4}$ An exception is Beine et al. (2001), who found a positive and significant effect of migration prospects on human capital formation in a cross-section of 37 developing countries. However, their study suffers from the fact that due to data constraints, they used gross migration rates as a proxy measure for the brain drain .
} 
countries.

The remainder of this paper is organized as follows. Section 2 presents the theoretical framework and derives the main testable implications of the analysis. Section 3 details the procedure used by Docquier and Marfouk (2006) to compute emigration rates by educational attainment and summarizes their data. The empirical analysis is divided between Section 4, which discusses a number of econometric issues and then presents the cross-sectional results, and Section 5, dedicated to country-specific calculations. Section 6 concludes.

\section{Theoretical and empirical framework}

Theoretical background. Consider a stylized small open developing economy where output is proportional to labor measured in efficiency units ${ }^{5}, Y_{t}=w_{t} L_{t}$. Due to exogenous inter-country productivity differentials, the equilibrium wage rate in this economy, $w_{t}$, is lower than in the developed nations. At birth, individuals are endowed with a given level of human capital normalized to one. They live for two periods, and make two decisions: whether to invest in education during their youth, and whether to migrate in adulthood. There is a unique education program $e$. For an individual opting for education, the number of efficiency units once adult is given by $h>1$ while the cost of education, which is decreasing in personal ability, is denoted by $c$, a variable with cumulative distribution $F(c)$ and density function $f(c)$ defined on $R^{+}$.

Once adult, people can emigrate to a high-wage destination with probability $p$ for

\footnotetext{
${ }^{5}$ Assuming a constant-returns-to-scale production function with physical capital and labor would give the same outcome provided that physical capital is perfectly mobile across countries. The international interest rate would determine the levels of capital per worker and wages. Output would then be proportional to $L$.
} 
skilled workers and $\underline{p}$ for unskilled workers. As explained in our introduction, selective immigration policies, together with the tendency for migrants to positively self-select out of the general population, explain why emigration rates are much higher among the highly educated and skilled. For example, Docquier and Marfouk's (2006) data, detailed in Section 3 below, reveal that emigration propensities are five to ten times higher for workers with more than twelve years of education than for workers with less than twelve years of education. We will therefore assume that $p>\underline{p}$. For analytical simplicity, we normalize $\underline{p}$ to zero. Also, in what follows we treat $p$ as exogenous, as if it was the result of a relative quota set by immigration authorities in the destination country independently of the number of potential visa applicants. However, we could equally assume that a given number of visas is attributed, which can be translated into a probability of receiving an entry visa by agents with rational (in which case the adjustment is immediate) ${ }^{6}$ or adaptative (in which case the subjective and objective probabilities only coincide at the steady state) expectations with respect to others' education decisions. ${ }^{7}$

Individuals are assumed to be risk-neutral and maximize lifetime income. There is no intertemporal discounting of income. As explained, unskilled workers are assumed to remain in the home country and therefore earn the domestic wage $w$ in both periods. In contrast, skilled workers have the possibility to migrate to a technologically more advanced country where the wage rate per efficiency unit of human capital is $w^{*}>w$. They earn $w-c$ in the first period and then either $w^{*} h$ if they migrate or $w h$ if they don't. For a given migration probability $p$, the condition for investing in

\footnotetext{
${ }^{6}$ Formally, $p$ can be a decreasing function of $c_{p}(p)$ in (1), defining an implicit solution for $p$.

${ }^{7}$ In the empirical analysis, however, it will be important to assess the exogeneity of the migration probability.
} 
education is therefore:

$$
w_{t}-c+(1-p) w_{t+1} h+p w_{t+1}^{*} h>w_{t}+w_{t+1}
$$

and individuals will opt for education if

$$
c<c_{p, t} \equiv w_{t+1}(h-1)+p h\left(w_{t+1}^{*}-w_{t+1}\right)
$$

Clearly, migration prospects raise the expected return to human capital in the developing country, thus inducing more people to invest in education. The critical threshold $c_{p, t}$ is increasing in the probability of migration and in the wage differential with the destination country. This suggests that the incentive effect of migration will be stronger in poor countries. However, credit constraints on education investments are likely to be more binding in poor countries. To take this into account, we introduce a minimum threshold of first-period consumption, $\mu_{t}$, which must be financed out of first-period earnings. Hence, for any educated individual, it must be the case that $w_{t}-c>\mu_{t}$ or, equivalently, that:

$$
c<c_{l, t} \equiv w_{t}-\mu_{t}
$$

Liquidity constraints are binding if $c_{l, t}<c_{p, t}$, that is, if $w_{t}-w_{t+1}(h-1)-p h\left(w_{t}^{*}-\right.$ $\left.w_{t}\right)<\mu_{t}$. At the steady state (i.e., for $w_{t}=w_{t+1}$ ), the binding liquidity constraints condition may be written as:

$$
w(2-h)-p h\left(w^{*}-w\right)<\mu .
$$

We therefore impose the restriction that $h \in[1,2]$ to allow for the possibility of either binding or non-binding constraints, depending on the value of $w$. It is clear from the last expression that liquidity constraints are more likely to be binding in poor countries (low $w$ ) facing high emigration rates (high $p$ ). 
We denote by $H_{a, t}$ and $H_{p, t}$ respectively the gross or ex-ante (i.e., before migration occurs) and the net or ex-post (i.e., once emigration is netted out) proportions of educated in the population, which we take as a measure of the country's human capital level. The proportion of young agents opting for education is given by $H_{a, t}=F\left(c_{t}^{*}\right)$ where $c_{t}^{*}=\operatorname{Min}\left(c_{p, t}, c_{l, t}\right)$ while the proportion of skilled adults remaining in the country is given by:

$$
H_{p, t}=\frac{(1-p) H_{a, t-1}}{1-p H_{a, t-1}}
$$

At the steady state, we have

$$
\frac{\partial H_{p}}{\partial p}=\frac{(1-p) \frac{\partial H_{a}}{\partial p}-H_{a}\left(1-H_{a}\right)}{\left(1-p H_{a}\right)^{2}}
$$

Using the above expression, it appears that:

- There is a possibility of beneficial brain drain over some ranges of $p$ providing that $\frac{\partial H_{p}}{\partial p}$ is positive at $p=0$. This first requires that $\frac{\partial H_{a}}{\partial p}$ is positive (i.e., there is an incentive effect), which implies that liquidity constraints are not binding in the closed economy;

- At the margin, an increase in the rate of skilled emigration is good for human capital formation if $\frac{\partial H_{p}}{\partial p}$ is positive at the current emigration rate. Again, this first requires that liquidity constraint are not binding, but this time at the current level of $p$;

- Finally, the total or net effect of migration on human capital formation can be obtained by comparing the ex-post (or net) level of human capital with its counterfactual level in the closed economy solution, $H_{p \mid p=0}=H_{a \mid p=0} \equiv \widetilde{H}$. There is a beneficial brain drain if the net effect is positive, that is, if $H_{p}>\widetilde{H}$. 
As explained, the realization of these conditions depends on whether liquidity constraints are binding as well as on the ability distribution. For illustrative purposes, let us consider the case of a uniform distribution: $c \rightsquigarrow U[0,1]$ and assume $\mu<w \leq 1$ to avoid corner solutions. With a uniform distribution, $H_{a}=c^{*}=\operatorname{Min}\left(c_{p}, c_{l}\right)$. Starting from a closed economy equilibrium, three configurations arise.

The most pessimistic one occurs when liquidity constraints are binding in the closed economy. In this case, when $w(2-h)<\mu$ (i.e., when the domestic wage rate is low), there can be no incentive effect: $\frac{\partial H_{a}}{\partial p}=0$. Hence, any marginal increase in the skilled migration probability would generate a net loss:

$$
\frac{\partial H_{p}}{\partial p}=\frac{-(w-\mu)(1-w+\mu)]}{(1-p[w-\mu])^{2}}<0
$$

Obviously, in this case the brain drain can only be detrimental $\left(H_{p}<\widetilde{H}\right)$.

An intermediate configuration arises when liquidity constraints are not binding in the closed economy but become binding once migration prospects are introduced. In this case, when $w(2-h)>\mu>w(2-h)-p h\left(w^{*}-w\right)$ (i.e., when the domestic wage rate is not too low and the migration rate is relatively high), a sufficiently small degree of openess can foster ex-post (or net) human capital if $\frac{\partial H_{p}}{\partial p}$ is positive at $p=0$, that is if

$$
h\left(w^{*}-w\right)>w(h-1)[1-w(h-1)]
$$

However, at the current migration rate, a marginal increase in $p$ reduces the proportion of educated remaining in the economy as binding credit constraints do not allow for the incentive effect to operate further $\left(\frac{\partial H_{a}}{\partial p}=0\right)$. The net effect is positive $\left(H_{p}>\widetilde{H}\right)$ if the skilled emigration probability does not exceed the following critical value:

$$
p<\frac{w(2-h)-\mu}{(w-\mu)(2-h)}
$$


The most optimistic case arises when liquidity constraints are never binding, thus allowing for the incentive effect to fully operate. In this case, obtained when $w(2-$ $h)-p h\left(w^{*}-w\right)>\mu$ (i.e., when the domestic wage rate is high enough and the skilled emigration rate is sufficiently low), the condition for a sufficiently small degree of openess to foster net human capital formation is the same as in (4) and the net effect is positive $\left(H_{p}>\widetilde{H}\right)$ when the skilled emigration rate does not exceed the following critical value:

$$
p<\frac{h\left(w^{*}-w\right)-w(h-1)[1-w(h-1)]}{h\left(w^{*}-w\right)[1-w(h-1)]}
$$

Finally, the sign of $\frac{\partial H_{p}}{\partial p}$ evaluated at the current migration rate can be positive or negative depending on the wage differential and on the magnitude of emigration. When $p$ tends to one, clearly, $\frac{\partial H_{p}}{\partial p}$ is more likely to become negative.

On the whole, our simple theoretical model predicts that migration prospects can stimulate the accumulation of human capital in developing countries under certain conditions: first, there must be an incentive effect (or brain gain), and second, the latter must be greater than actual skilled emigration (or brain drain). The incentive effect would seem to be potentially stronger in poor countries but may be limited there if liquidity constraints are binding. It is therefore a priori unclear whether poor or intermediate income countries experience the strongest incentive effects and, consequently, it is also unclear which type of countries gain or lose more from the brain drain.

Related empirical model. To evaluate the incentive hypothesis described theoretically in (1), we use a $\beta$-convergence empirical model and regress the growth rate of the ex-ante stock of human capital (i.e., including emigrants) between 1990 and $2000, \Delta \ln \left(H_{a}\right)$, on a set of explanatory variables. It is this human capital formation 
equation, Equation (6), that we estimate econometrically in Section 4. Together with two tautological equations defining the change in the ex-ante stock (Equation 5) and the method for computing the ex-post stock of human capital (Equation 7), it forms the following basic empirical model:

$$
\begin{aligned}
\Delta \ln \left(H_{a, 90-00}\right) \equiv & \ln \left(H_{a, 00}\right)-\ln \left(H_{a, 90}\right) \\
\Delta \ln \left(H_{a, 90-00}\right)= & a_{0}+a_{1} \cdot \ln \left(H_{a, 90}\right)+a_{2} \cdot \ln \left(p_{90}\right)+a_{3} \cdot \ln \left(p_{90}\right) \cdot G N I D_{90} \\
& +a_{4} \cdot D E N S_{90}+a_{5} \cdot S S A D+a_{6} \cdot L A T D+a_{7} \cdot R M_{90}+\epsilon \\
H_{p, 2000} \equiv & \frac{\left(1-p_{2000}\right) H_{a, 2000}}{1-p_{2000} H_{a, 2000}-\underline{p}_{2000}\left(1-H_{a, 2000}\right)}
\end{aligned}
$$

Note that while we neglected unskilled migration in the theoretical model by setting unskilled migrants'probability to zero, this is clearly not satisfactory from an empirical perspective. We therefore include unskilled migration in our computation of the post-migration human capital stock in (7), where we denote the unskilled emigration rate by $\underline{p}_{2000}$. This variable will play an important role when we will introduce counterfactual simulations to estimate the net effect of skilled migration on human capital formation in Section 5.

The following explanatory variables enter in the estimation of Equation (6): ${ }^{8}$

- The $\log$ of the initial level of ex-ante human capital, $\ln \left(H_{a, 90}\right)$, to capture potential catching-up effects. A negative sign for the coefficient $a_{1}$ would indicate convergence in natives' (residents plus emigrants) human capital among the countries sampled.

- The log of the skilled migration rate at the beginning of the period, $\ln \left(p_{90}\right)$, as a proxy for the migration incentives faced by educated individuals. Ideally, the

\footnotetext{
${ }^{8}$ The data sources are given in the Appendix.
} 
incentive effect of migration on human capital investment should be identified through the impact of migration prospects on expected returns to education. However, these cannot be computed directly as there are no comparative data on education premia in developing countries. Using differences in GNI per capita, on the other hand, raises endogeneity concerns as this variable is strongly correlated with human capital. In our benchmark model, we will thus let aside wage differentials and differences in GNI per capita and use instead $\ln \left(p_{90}\right)$. A positive sign for the coefficient $a_{2}$ indicates that the incentive effect operates (i.e., there is a brain gain). Still, one may be concerned about possible nonlinearities in the relationship between migration prospects and human capital formation at different income levels. In alternative specifications, we allow for this possibility by interacting this initial skilled emigration rate, $\ln \left(p_{90}\right)$, with dummy variables for whether the country's income per capita was lower than a given threshold at the beginning of the period, GNID $D_{90}$. A negative sign for the coefficient $a_{3}$ would suggest that the impact of higher liquidity constraints more than offsets that of higher wage differentials, resulting in a weaker incentive effect in poor countries. Obviously, robustness checks imply the use of different possible thresholds.

- The population density in $1990, D E N S_{90}$, as a proxy for the cost of acquiring education. Clearly, education costs depend on a host of factors such as public expenditures on general and higher education, distances to schools, etc. However, public expenditures on education at the beginning of the sample period (in 1990) are statistically very highly correlated in our sample with the initial level of human capital $H_{90}$. This certainly suggests that such expenditures are 
effective, but the magnitude of the correlation (0.72) precludes any correct joint estimation of the impact of public expenditures and of possible convergence effects. Population density is likely to reduce distances to schools and, therefore, to decrease the opportunity cost of education.

- Workers' remittances as a share of GDP, $R M_{90}$, first because they can relax credit constraints on human capital investment, and second, because in the absence of statistics on return migration, they provide an indirect means of controlling for possible returns in subsequent periods. ${ }^{9}$

- Regional dummies for sub-Saharan Africa $(S S A D)$ and Latin America ( $L A T D)$.

\section{Data on human capital and migration rates}

Until very recently, there were no comparative data on the magnitude of the brain drain. The first serious effort to put together harmonized international data on migration rates by education level is due to IMF economists Carrington and Detragiache (1998). They used US 1990 Census data and other OECD statistics on international migration to construct estimates of emigration rates at three education levels: primary (0 to 8 years of completed schooling), secondary (9 to 12 years) and tertiary (13 years and above), for about 60 developing countries. The Carrington-Detragiache (henceforth CD) estimates, however, suffer from three main shortcomings. First, CD assumed for each country that the skill composition of its emigration to non-US OECD countries is identical to that of its emigration to the US; for example, Nigerian immigrants in the UK were assumed to be distributed across educational categories in

\footnotetext{
${ }^{9}$ Indeed, preparing one's return is known to be a central motivation to remit and remittances tend to decline over time as migrants become better integrated in the host country, families are reunited and return prospects diminish. See Rapoport and Docquier (2006) for a comprehensive survey of migrants remittances.
} 
the same way as Nigerian immigrants in the US. Consequently, the CD estimates are not reliable for countries for which the US is not the main destination (transposition problem). Second, at the time CD conducted their study, the OECD immigration data (notably for the EU, Japan, Switzerland or New Zealand) did not allow for a full decomposition of the immigrants' origin-mix; more precisely, many OECD countries used to publish statistics indicating the immigrants' origin country for the top 5 or 10 source countries only. For small countries not captured in these statistics, the figures reported in the CD database are therefore biased: the total number of emigrants is under-estimated, and in some cases one is (mis)led to conclude that $100 \%$ of a given country's workers who immigrated to an OECD member-country immigrated to the US (under-reporting problem); as acknowledged by Carrington and Detragiache, this may approximate the reality for Latin America, but is clearly erroneous, for example, in the case of most African countries and of many Asian countries. And third, the CD data excludes South-South migration, which may be significant in some cases (e.g., migration to the Gulf States from Arab and Islamic countries, or to South-Africa from the neighboring countries).

Our empirical analysis is based on a new dataset on international migration by educational attainment, namely, on the World Bank sponsored Docquier and Marfouk (2006) (henceforth DM) dataset. ${ }^{10}$ DM collected data on immigration by education level and country of birth from nearly all OECD countries in 1990 and 2000, using the same methodology and definitions as Carrington and Detragiache (1998) but extending their work in a number of ways. First, census, register and survey data reporting immigrants' educational levels and countries of birth were used for 27 OECD

\footnotetext{
${ }^{10} \mathrm{We}$ used the CD estimates in an earlier version of this paper and found very similar results. See Beine et al. (2003). Adams (2003) extended the CD dataset to the year 2000, using the same extrapolations from the educational structure of US immigration.
} 
countries in 2000 (which account for 98 percent of the OECD immigration stock) and 24 countries in 1990 (91 percent). For the few remaining countries for which census data were not available, existing data by country of birth were splitted across educational levels on the basis of the regional structure or of the OECD average. On this basis, Docquier and Marfouk (2006) obtained reliable emigration rates by education level for 195 emigration countries in 2000 and 174 countries in 1990. They address two of the above-mentioned problems arising from the CD database: underreporting for small countries, and transposition of the US immigration education structure to the rest of the OECD (and, in addition, they provide data for a second year, 2000). As for the CD dataset, South-South migration is not taken into account; however, on the basis of census data collected from selected non-OECD countries, DM estimate that about 90 percent of all highly-skilled migrants live in the OECD area.

Aggregating over countries, it appears from the DM database that the total number of adult immigrants living in the OECD area and aged 25 or more may be estimated at 59 million for 2000 and 41.8 million for 1990. Table 1 summarizes their data for different country groups in 2000. Countries are grouped according to demographic size, average income (using the World Bank classification), and region. As expected, there is a decreasing relationship between emigration rates and country size, with average emigration rates being about 7 times higher for small countries (with population lower than 2.5 million) than for large countries (with population higher than 25 million). From the last two columns, we can see that these differences cannot be attributed to the educational structure of the home country population or to a higher 'selection bias' (ratio of skilled to total emigration rates) in small countries. Small countries simply tend to be more open to migration. The highest emigration rates 
are observed in middle income countries where people have both the incentives and means to emigrate. High income countries (low incentives) and low income countries (where liquidity constraints are likely to be more binding) exhibit the lowest rates. This holds true for both total and skilled migration. Regarding the regional distribution of the brain drain, the most affected regions appear to be the Caribbean and the Pacific, which consist of relatively small islands, Sub-Saharan Africa, and Central America. The difference between skilled and total emigration rates is particularly large in Africa.

\section{[INSERT TABLE 1]}

The method used by DM is to rely on receiving country $r$ 's census or population register to extract information on immigrants country of birth, age, and skill level. Let $M_{t, s}^{r}$ denote the stock of working-age individuals born in a given country, of skill level $s, s=l, m, h$ (for low, medium and high) and living in country $r$ at time $t$. The stock of emigrants from a given country for a given education level, $M_{t, s}=\sum_{r} M_{t, s}^{r}$, is then obtained by summing over receiving countries. Emigration rates by education levels are then obtained by comparing the number of emigrants to the population at origin with similar characteristics, $N_{t, s}$. For each education category, emigration rates are given by

$$
p_{t, s}=\frac{M_{t, s}}{N_{t, s}+M_{t, s}}
$$

and its share among the total native population (residents and emigrants included) by

$$
H_{a, t}=\frac{N_{t, h}+M_{t, h}}{\sum_{s}\left(N_{t, s}+M_{t, s}\right)} .
$$

These steps require collecting data on the size and skill structure of the workingage population in the origin countries. Population data by age are provided by the 
United Nations. ${ }^{11}$ Data are missing for a small number of countries but can be estimated using the CIA world factbook. ${ }^{12}$ Population data are split across educational groups using international human capital indicators. The DM data set is based on the Barro and Lee (2000) estimates for most countries. For countries where the Barro and Lee measures are missing, DM transposed the skill structure of the neighboring country with the closest human development index regarding education.

To conduct the empirical analysis, and given that we focus on the brain drain impact on developing countries, our sample excludes high-income countries as well as countries from the former USSR, Yugoslavia and Czechoslovakia (for consistency between the 1990 and the 2000 data points), which gives a total sample of 127 developing countries. We measure the emigration rate of skilled workers as the emigration rate among individuals with tertiary education: $p_{t}=p_{t, h}$. As emigration rates are strongly increasing in human capital, we will also assume that the minimal or incompressible emigration rate is the one observed among people with primary education: $\underline{p}_{t}=p_{t, l}$.

\section{Results}

Econometric issues. Before we carry out the estimations, we first address some specification issues. A first important question concerns the exogeneity of the migration rate. When trying to determine the impact of migration on education, one has to control for the reverse effect since, on average, the proportion of educated is likely to affect the rate of skilled migration. This is due to a number of causes. First, as standard neoclassical models would suggest, a larger stock of human capital may re-

\footnotetext{
${ }^{11}$ See http://esa.un.org/unpp.

${ }^{12}$ See http://www.cia.gov/cia/publications/factbook.
} 
duce the skill premium and thus increase skilled migration incentives through higher international wage differentials. However, a larger stock of human capital may also generate positive externalities on wages through a variety of channels emphasized in new growth and new economic geography models (see Klenow and Rodriguez-Clare, 2004). Second, with an immigration system based on quotas by country (as was the case for the US system until 1965), the higher the supply of skilled workers in the source country, the lower their probability to emigrate.

In an attempt to cope with this endogeneity issue, recent empirical growth analyses (e.g., Barro and Sala-I-Martin, 1995, Hall and Jones, 1999) have been concerned with the use of truly exogenous instruments. In these studies, the following variables have been suggested as candidate instruments for a first-stage migration equation:

- Life expectancy at birth $\left(L E_{90}\right)$, as a proxy for general living conditions;

- The country's population size $\left(P O P_{90}\right)$, as small countries tend to be more open to migration. Also, following the above discussion on immigration quotas, it is clear that if visas are delivered on a country basis they are likely to be more binding in the case of large countries;

- Racial tensions $(R A C)$, a key traditional "push" factor;

- The number of emigrants living in the OECD area at the beginning of the period $(M T)$, to capture the size of the migration network on which prospective emigrants can count on; ${ }^{13}$.

\footnotetext{
${ }^{13} \mathrm{As}$ is well known, larger networks are associated with lower migration costs (especially information-related ones) and higher expected wages; all else equal, they should act to increase the number of future migrants. See for example Carrington et al. (1996), Munshi (2003), and Kanbur and Rapoport (2005).
} 
- The GDP per capita of the source country, as a proxy for wage differentials clearly a driving force of migration.

We retain only two out of these five candidate instruments in our first-stage migration equation as we have to eliminate the variables for which there is a strong presumption of a correlation with human capital. This is the case for wage differentials, for obvious reasons, ${ }^{14}$ and for life expectancy, the exogeneity of which is questionable given the fact that longer-lived individuals can enjoy the benefits of education over a longer period of time. We also exclude racial tensions, for both technical and substantive reasons. Technically, their introduction would result in a significant drop in the size of the sample used in the instrumental variable (IV) estimation, which would lower the comparability with the OLS results. ${ }^{15}$ More substantively, it could well be that racial tensions impact on human capital formation, especially if ethnic discrimination is a serious issue. ${ }^{16}$ We are therefore left with two instrumental variables: total population size, and migration stocks at the beginning of the period. At a theoretical level, there is no obvious reason why the demographic size of a country should be correlated its education level. Likewise, there is no a priori reason why migration networks at destination should impact on human capital formation beyond their effect on migration prospects and incentives (captured by our instrumentation equation). Since we have only one endogeneous explanatory variable, the number of instruments is large enough to test for exogeneity of the retained intruments using a

\footnotetext{
${ }^{14} \mathrm{As}$ a crude test, the correlation between wage differentials and human capital levels is indeed higher than 0.5 .

${ }^{15}$ More precisely, the sample size falls to 59 countries when racial tensions are added to the set of instruments. We still obtain a positive incentive effect (of a higher magnitude) and conclude in favour of the exogeneity of the three instruments. The first-stage estimation also supports racial tensions as a strong instrument at the $10 \%$ significance level. The results with this specification are available from the authors upon request.

${ }^{16}$ See Tremblay (2001) and Docquier and Rapoport (2003).
} 
traditional overidentification test.

At an empirical level, the validity of our instruments rests on two conditions: the instruments should first be significantly correlated with the migration rate, and the exogeneity condition requires that they should be uncorrelated with the error term in (6).

Equation (8) reports the results of an OLS regression of the migration equation for the full sample on the two selected instruments (t-statistics are reported between brackets):

$$
\begin{aligned}
p & =\underset{(2.24)}{1.20}+\underset{(8.46)}{0.454} \ln (M T)-\underset{(-13.92)}{0.518} \ln (P O P) \\
R^{2} & =0.509 ; \text { Nobs }=127 ; F=97.14 .
\end{aligned}
$$

The two instruments are significant at the $1 \%$ significance level and are therefore kept throughout the analysis. Interestingly, population size enters with a negative sign; this supports the conjecture mentioned above, according to which immigration restrictions are more binding for larger countries. In turn, this further justifies the assumption that education decisions are taken in a context of uncertainty regarding future migration opportunities, as asssumed in the theoretical model. Note also that the sign of $\ln (M T)$ is in line with intuition: a higher initial stock of migrants stimulates future emigration. Together, the variables $\ln (M T)$ and $=\ln (P O P)$ account for more than $50 \%$ of the migration variability, which is quite satisfactory for a crosssection analysis. A more formal test relies on the value of the $F$ statistics testing the null hypothesis that all coefficients in (8) jointly equal zero. The test reveals that this null hypothesis is clearly rejected, suggesting that the two instruments are strong. Finally, given that we have more instruments than endogeneous variables, a $J$-test of overidentification was also run to assess the exogeneity property of the 
retained instruments, the p-values of which are reported in the result tables below. For the parcimonious specification, the test supports the exogeneity assumption of the two instruments, thus providing additional confidence that our instruments are indeed uncorrelated with the human capital variable.

Testing for incentive effects. We now turn to the estimation of equation (6). Table 2 reports the estimation results for the full specification and for a more parcimonious model from which insignificant variables such as LATD, DENS90 and REM90 were excluded. Exclusion of these variables leads to a significant increase of the number of countries included (from 103 to 127) as the variable $R E M 90$ displays missing values. The results appear to be very robust to the choice of specification and of the estimation technique (OLS and IV). Skilled migration appears to significantly increase gross (or ex-ante, or pre-migration) human capital stocks. The value of the migration coefficient lies between 0.042 and 0.050 for the OLS estimate (depending on whether the constant and the insignificant explanatory variables are included) and is slightly higher (0.050) after instrumenting. ${ }^{17}$ Taken literally, this means that doubling the migration propensity of the highly skilled increases gross human capital formation by 5 percent. This is not negligible in countries where the proportion of highly educated typically lies in the 2-8 percent range and higher education significantly increases (by a factor of 5 to 10) one's chances of emigration.

\section{[INSERT TABLE 2]}

Regarding the other control variables, we find evidence of convergence in human capital levels among the developing countries sampled. Indeed, the coefficient on the

\footnotetext{
${ }^{17}$ The IV results obtained without a constant are not reported here to save space. In this regression, the estimated incentive effect amounts to 0.057 . We obtain similar results with respect to the Hausman test and the over-identification test.
} 
lagged human capital stock is negative and significant at the one percent threshold in all specifications. Moreover, in line with the findings of Easterly and Levine (1997), we find that Sub-Saharian countries display poor performances in terms of human capital formation. In contrast, population density and the dummy variable for LatinAmerica do not seem to exert any significant impact and are therefore omitted in the parcimonious specifications. Finally, workers' remittances are also insignificant in all regressions and are therefore left aside throughout the rest of the empirical analysis (and, in addition, this also addresses possible endogeneity concerns). While the overidenfication test supports the exogeneity of the two instruments in the parcimonious specification, the Hausman test does not support the need for accounting for reverse causality. The $p$-values associated with this test for the two specifications considered are indeed above the usual significance levels.

Regardless of the retained specification and the estimation method, we always find a positive incentive effect in the sense that the coefficient of the rate of migration is significantly positive at a 5 percent level (10 percent in column (1)). The benchmark elasticity of human capital formation to skilled migration is obtained in column (3) of Table 2. In this best parcimonious specification, we have $a_{2}=4.81$ percent. Using the standard error of the coefficient, we can also provide an interval of confidence at 90 percent for the elasticity. The lower bound for $a_{2}$ is equal to 1.37 percent and the upper bound amounts to 8.25 percent. Hence, the incentive effect is definitely positive.

Testing for non-linearities. Until now, the regressions have assumed that the incentive effect of migration on education is homogeneous across countries. To test for possible non-linearities in equation (6), we interact skilled migration rates with a dummy variable for low-income status. To define a "poor country" we use three 
alternative threshold values of the 1990 GNI per head (500, 750 and 900 US\$). We augment the benchmark specification by adding the interaction term $\ln \left(p_{90}\right)$.GNID to the set of explanatory variables of equation (6), where GNID is a dummy variable equal to 1 if country $i$ is a low income country. The advantage of this specification is that the correlation between the raw migration rate and the interaction term remains modest, which moderates the statistical effects of collinearity. Table 3 reports the results with this specification. As the Hausman test conducted above tended to confirm the exogeneity of the migration rate, we only present the OLS results for the specification with interaction terms. ${ }^{18}$

On the whole, the results do not provide any evidence of a different impact for the poorest countries. In all regressions, the interaction term $\ln \left(p_{90}\right) . G N I D$ is insignificant at usual significance levels. Interestingly, the value of the migration coefficient, $\ln \left(p_{90}\right)$, seems unaffected by the inclusion of interaction terms. However, one may be concerned that in the absence of information on income distribution, average income levels may only imperfectly capture the extent of liquidity constraints. In unreported regressions, we also interacted skilled migration with a dummy variable $P O O R$ for whether more than $40 \%$ of the country's population live with less than one dollar per day. As with the previous definition, no significant differences were found between poor and richer countries, leading us to conclude to the absence of non-linearities in the skilled migration-human capital formation relationship.

\section{[INSERT TABLE 3]}

\footnotetext{
${ }^{18}$ Using the values of $p_{90}$ predicted by the first stage migration regression leads to similar estimates. These results are available upon request.
} 


\section{Country-specific results}

The cross-sectional results just derived show that migration prospects have a significant positive impact on gross human capital formation. From the perspective of source countries however, what matters is not the number of people who acquire education but the number of educated who remain in the country after education is acquired. To evaluate whether the country has experienced a brain gain or a brain drain, one must compare its observed human capital level to some relevant counterfactual. Since the incentive effect emphasized above relies on skill-biased migration prospects, a natural counterfactual experiment to make is to keep the skill premium constant with and without migration. To derive the country-specific effects of the brain drain, we thus compare current human capital levels to their erstwhile value would skilled workers be allowed to emigrate at the same rate as unskilled workers. ${ }^{19}$

Our simulations are based on the coefficient obtained in the best parcimonious specification presented in column 3 of Table 2 (i.e., $a_{2}=0.0481$ ). Since $\underline{p}_{90}<p_{90}$, the counterfactual proportion of tertiary educated natives, $H_{a, 2000}^{c f}$, is always lower than the actual proportion, $H_{a, 2000}$. The simulation system is given by the following equations:

$$
\begin{aligned}
& H_{a, 2000}^{c f}=H_{a, 2000}-a_{2} \cdot \ln \left(p_{90} / \underline{p}_{90}\right) \\
& H_{p, 2000}^{c f}=H_{a, 2000}^{c f}
\end{aligned}
$$

The results of this counterfactual experiment are given in Table 4. For each country of the sample, we measure the human capital gain/loss associated to the brain drain as the difference between current and counterfactual proportions of skilled. The

\footnotetext{
${ }^{19}$ For a small number of countries where the unskilled emigration is close to zero, we impose a lower bound equal to 10 percent of the skilled emigration rate. Since we use a log specification, this avoids unrealistic effects.
} 
countries are ranked in Table 4 by decreasing gain. As may be seen from the Table, there are slightly more losers than winners. More importantly, the gains of the winners are relatively small and exceed $1 \%$ of the country's skilled labor force only in a handful of cases. In contrast, the losses of the losers can be substantial and exceed $10 \%$ in many small Carribean and Pacific countries.

\section{[INSERT TABLE 4]}

A more general pattern emerges when the gains and losses in terms of human capital formation are plotted against two key characteristics: the magnitude of the skilled emigration rate in 1990, and the observed proportion of educated natives in 1990. It appears that the countries experiencing a positive net effect (the 'winners') generally combine low levels of human capital and low skilled migration rates, whereas the 'losers' are typically characterized by high skilled migration rates (above 20\%) and/or high enrollment rates in higher education (above 5\%). Figure 1 and 2 give the reduced-form relationship between the human capital impact of the brain drain and these two variables. For each relationship, we estimate a quadratric reduced-form adjustment. The relationships are very significant and exhibit high $R^{2}$ (respectively 61 and 37 percent).

\section{[INSERT FIGURES 1 and 2]}

Finally, it is striking from Table 4 that the most populated countries (e.g., China, India, Indonesia, Brazil, Egypt, Bangladesh) are all among the winners. Once translated into absolute numbers, their relatively modest gains more than offset the losses of the many small countries hardly hurt by the brain drain. This is more apparent from Table 5, which gives the results for country groups defined according to demographic size, income level, and region. On aggregate, there are 116.5 million skilled 
workers living in the 127 developing countries of our sample in 2000 (representing about $5 \%$ of the sample's labor force). This number would fall to 113.2 million under the counterfactual scenario, meaning that the brain drain generates according to our computations a $3 \%$ increase in the total number of skilled workers living in the developing world.

\section{[INSERT TABLE 5]}

Disaggregating by demographic size, income level and region, it is noteworthy that:

- Large countries (with population higher than 25 million) form the only group to experience a net gain while losses are concentrated on the relatively small countries (with population lower than 10 million). For the smallest countries (with population lower than 1 million), the losses are substantial once expressed in relative terms as they represent a $33 \%$ percent net loss.

- There is no clear pattern for the decomposition by income levels (2000 classification).

- At a regional level, the brain drain appears to be extremely detrimental in Central America (especially in the Carribean), the Pacific region, and to a lower extent in Sub-saharan Africa, while Asia and South America experience significant gains.

\section{Conclusion}

The brain drain has long been viewed as a serious constraint on poor countries development. However recent theoretical literature suggests that migration prospects 
can raise the expected return to human capital and foster investment in education at home. This paper empirically investigates how these positive and negative effects balance out. Using recent data on emigration rates by education levels (Docquier and Marfouk, 2006), we find evidence of a positive effect of skilled migration prospects on gross (pre-migration) human capital levels in a cross-section of 127 developing countries. More precisely we find that the elasticity of human capital investment to skilled migration is equal to about $5 \%$ and is very stable across specifications and estimation methods. For each country we then estimate the net effect of the brain drain using counterfactual simulations. We find that countries combining relatively low levels of human capital and low skilled emigration rates are likely to experience a net gain, and conversely. There appears to be more losers than winners, and in addition the former tend to lose relatively more than what the latter gain. The situation of many small countries in Sub-Saharan Africa and Central America, in particular, is extremely worrisome. In contrast, the main globalizers (e.g., China, India, Brazil) all seem to experience non-negligible gains.

Two central conclusions emerge from the above analysis. First, brain drain migration contributes to an increase in the number of skilled workers living in the developing countries. This suggests that the traditional perception of the brain drain, often viewed as a kind of predation through which rich countries extract the most valuable human resources from the poor countries, has no empirical justification at an aggregate level. Second, there are winners and losers. In other words, the brain drain has important distributional effects among developing countries, a dimension that has so far been absent from policy debates.

This paper offers initial insights on the general circumstances under which a beneficial or a detrimental brain drain is obtained. However, further empirical research 
is needed before policy conclusions can be derived with more confidence. In particular, due to the unavailability of panel data on international migration by education level, cross-country comparisons are currently unable to fully capture the dynamic relationship between migration and human capital formation. In addition, without a time-series dimension, it is also impossible to control for unobserved heterogeneity in the regression estimates. Given the strong heterogeneity of developing countries in terms of sizes, income levels, etc., such effects are likely to play a significant role. Another important direction for future empirical research is to control for immigrants age of entry. This is an essential step as only people who acquired education in their home country can truly be defined as "highly-skilled emigrants" from that country. Controlling for age of entry is unlikely to modify the broad picture but could make a significant difference in some specific cases. ${ }^{20}$ Finally, the sectoral composition of emigration could be of tremendeous importance, especially if the brain drain disproportionately affects specific professions (e.g., health professionals, engineers) whose presence at home strongly conditions the productive potential of others.

\section{$7 \quad$ References}

- Adams, R. (2003): International migration, remittances and the brain drain: a study of 24 labor-exporting countries, World Bank Policy Research Working Paper No. 2972.

- Barro, R. and J.W. Lee (1993): International measures of schooling years and schooling quality, American Economic Review, Papers and Proceedings, 86, 2: 218-23.

- Barro, R. and X. Sala-I-Martin (1995): Economic Growth, New-York: McGraw Hill.

\footnotetext{
${ }^{20}$ For example, less than 18 percent of all highly skilled immigrants living in the US in 2000 entered the country before age 18 .
} 
- Beine, M., F. Docquier and H. Rapoport (2001): Brain drain and economic growth: theory and evidence, Journal of Development Economics, 64, 1: 275-89.

- Beine, M., F. Docquier and H. Rapoport (2003): Brain drain and LDCs' growth: winners and losers, IZA Discussion Paper No 819, July.

- Bhagwati, J.N. and K. Hamada (1974): The brain drain, international integration of markets for professionals and unemployment, Journal of Development Economics, 1, 1: $19-42$.

- Carrington, W.J. and E. Detragiache (1998): How Big is the Brain Drain?, IMF Working Paper, No 98.

- Carrington, W.J, E. Detragiache, and T. Vishwanath (1996): Migration with endogenous moving costs, American Economic Review, 86, 4: 909-30.

- Commander, S., M. Kangasniemi, and L.A. Winters (2004): The brain drain: curse or boon? A survey of the literature, in R. Baldwin and L.A. Winters, eds.: Challenges to Globalization, NBER and University of Chicago Press, Chapter 7.

- Docquier, F. and A. Marfouk (2006): International migration by education attainment, 1990-2000; In: C. Ozden and M. Schiff (eds): International migration, brain drain and remittances, New York: McMillan and Palgrave. Chapter 5, pp. 151-99.

- Docquier, F. and H. Rapoport (2003): Ethnic discrimination and the migration of skilled labor, Journal of Development Economics, 70, 1: 159-72:

- Docquier, F. and H. Rapoport (2004): Skilled migration: the perspective of developing countries, World Bank Policy Research Working Paper No 3382, August. 
- Easterly, W. and R. Levine (1997): Africa's growth tragedy: policies and ethnic divisions, Quarterly Journal of Economics, 112, 4: 1203-50.

- Grubel, H. G. and A. Scott (1966): The international flow of human capital, American Economic Review, 56: 268-74.

- Hall, R.E. and C.I. Jones (1999): Why do some countries produce so much more output per worker than others?, Quarterly Journal of Economics, 114, 1: 83-116.

- Haque, N.U and S.-J. Kim (1995): 'Human capital flight': impact of migration on income and growth, IMF Staff Papers, 42, 3: 577-607.

- ILO (2006): Competing for Global Talent, Geneva: International Labor Office.

- Kanbur, R. and H. Rapoport (2005): Migration selectivity and the evolution of spatial inequality, Journal of Economic Geography, 5, 1: 43-57.

- Klenow, P. J. and A. Rodriguez-Clare (2004): Externalities and growth, NBER Working Paper No 11009, December.

- McCormick, B. and J. Wahba (2000): Overseas unemployment and remittances to a dual economy, Economic Journal, 110: 509-34.

- McCullock, R. and J.T. Yellen (1977): Factor mobility, regional development and the distribution of income, Journal of Political Economy, 85, 1: 79-96.

- Miyagiwa, K. (1991): Scale economies in education and the brain drain problem, International Economic Review, 32, 3: 743-59.

- Mountford, A. (1997): Can a brain drain be good for growth in the source economy?, Journal of Development Economics, 53, 2: 287-303. 
- Munshi, K. (2003): Networks in the modern economy: Mexican migrants in the US labor market, Quarterly Journal of Economics, 118, 2: 549-99.

- Rapoport, H. and F. Docquier (2006): The economics of migrants' remittances, in S.C. Kolm and J. Mercier Ythier, eds.: Handbook of the Economics of Giving, Altruism and Reciprocity, Amsterdam: Elsevier-North Holland, forthcoming.

- Stark, O., C. Helmenstein and A. Prskawetz (1997): A brain gain with a brain drain, Economics Letters, 55: 227-34.

- Todaro, M. and S.C. Smith (2006): Economic Development, Pearson and AddisonWesley, ninth edition.

- Tremblay, K. (2001): Ethnic conflicts, migration and development, Unpublished PhD dissertation, University of Paris I-Sorbonne.

- Vidal, J.-P. (1998): The effect of emigration on human capital formation, Journal of Population Economics, 11, 4: 589-600.

- Wong, K.-Y. and C.K. Yip (1999): Education, economic growth, and brain drain, Journal of Economic Dynamics and Control, 23, 5-6: 699-726.

- World Bank (2005): World Development Indicators, Washington: The World Bank. 


\section{Appendix: Data sources}

- Data on human capital levels $\left(H_{a, t}\right.$ and $\left.H_{p, t}\right)$, emigration rates $\left(p_{t}\right.$ and $\left.\underline{p}_{t}\right)$ and total stocks of emigrants $\left(M T_{t}\right)$ are taken from from Docquier and Marfouk (2006).

- Data on GNI and GDP per capita, population size $\left(P O P_{t}\right)$ and population density $\left(D E N S_{t}\right)$, life expectancy at birth $\left(L E_{t}\right)$ and workers' remittances $\left(R M_{t}\right)$ are taken from the World Development Indicators (World Bank, 2005). The GNI per capita is measured in US\$, using the Atlas method. The GDP per capita is measured in constant 2000 US\$.

- Data on racial tensions $(R A C)$ come from the International Country Risk Guide (1984)

- Regional dummies $S S A D$ and $L A T D$ are according to the commonly used World Bank classification

- Dummies based on poverty rates $(P O O R)$ are taken from the United Nations. We use the 1900-2003 average proportion of the population living with less than $\$ 1$ a day. 


\section{Table 1 : Migration data by country group}

\begin{tabular}{|c|c|c|c|c|c|c|c|c|}
\hline \multirow[b]{2}{*}{ By country size } & \multirow{2}{*}{$\begin{array}{c}\begin{array}{c}\text { Share in the world } \\
\text { population }\end{array} \\
\text { in } \% \\
\end{array}$} & \multicolumn{2}{|c|}{$\begin{array}{c}\text { Share in the OECD immigration } \\
\text { stock }\end{array}$} & \multicolumn{3}{|c|}{ Rate of emigration } & \multicolumn{2}{|c|}{ Share of skilled workers } \\
\hline & & Total & Skilled & Total & Skilled & Skilled/Total & $\begin{array}{c}\text { Among } \\
\text { residents }\end{array}$ & $\begin{array}{c}\text { Among } \\
\text { migrants }\end{array}$ \\
\hline Large countries (Pop $>25$ million) & $84.2 \%$ & $60.6 \%$ & $63.9 \%$ & $1.3 \%$ & $4.1 \%$ & 3.144 & $11.3 \%$ & $36.4 \%$ \\
\hline Upper-Middle $(25>$ Pop $>10)$ & $10.0 \%$ & $15.8 \%$ & $15.2 \%$ & $3.1 \%$ & $8.8 \%$ & 2.839 & $11.0 \%$ & $33.2 \%$ \\
\hline Lower-Middle (10>Pop>2.5) & $5.2 \%$ & $16.4 \%$ & $15.7 \%$ & $5.8 \%$ & $13.5 \%$ & 2.338 & $13.0 \%$ & $33.1 \%$ \\
\hline Small countries $(\mathrm{Pop}<2.5)$ & $0.6 \%$ & $3.7 \%$ & $3.7 \%$ & $10.3 \%$ & $27.5 \%$ & 2.666 & $10.5 \%$ & $34.7 \%$ \\
\hline By income group & in $\%$ & Total & Skilled & Total & Skilled & Skilled/Total & $\begin{array}{c}\text { Among } \\
\text { residents }\end{array}$ & $\begin{array}{c}\text { Among } \\
\text { migrants }\end{array}$ \\
\hline High Income countries & $16.0 \%$ & $30.4 \%$ & $33.7 \%$ & $2.8 \%$ & $3.5 \%$ & 1.238 & $30.7 \%$ & $38.3 \%$ \\
\hline Upper-Middle Income countries & $10.3 \%$ & $24.3 \%$ & $17.7 \%$ & $4.2 \%$ & $7.9 \%$ & 1.867 & $13.0 \%$ & $25.2 \%$ \\
\hline Lower-Middle Income countries & $15.6 \%$ & $26.6 \%$ & $27.2 \%$ & $3.2 \%$ & $7.6 \%$ & 2.383 & $14.2 \%$ & $35.4 \%$ \\
\hline Low Income countries & $58.1 \%$ & $15.1 \%$ & $19.8 \%$ & $0.5 \%$ & $6.1 \%$ & 12.120 & $3.5 \%$ & $45.1 \%$ \\
\hline By region & in $\%$ & Total & Skilled & Total & Skilled & Skilled/Total & $\begin{array}{c}\text { Among } \\
\text { residents }\end{array}$ & $\begin{array}{c}\text { Among } \\
\text { migrants }\end{array}$ \\
\hline AMERICA & $13.6 \%$ & $27.2 \%$ & $22.9 \%$ & $3.3 \%$ & $3.3 \%$ & 1.002 & $29.6 \%$ & $29.7 \%$ \\
\hline USA and Canada & $5.2 \%$ & $2.9 \%$ & $4.7 \%$ & $0.8 \%$ & $0.9 \%$ & 1.127 & $51.3 \%$ & $57.9 \%$ \\
\hline Caribbean & $0.5 \%$ & $5.3 \%$ & $5.8 \%$ & $15.3 \%$ & $42.8 \%$ & 2.807 & $9.3 \%$ & $38.6 \%$ \\
\hline Central America & $2.2 \%$ & $14.2 \%$ & $6.7 \%$ & $11.9 \%$ & $16.9 \%$ & 1.418 & $11.1 \%$ & $16.6 \%$ \\
\hline South America & $5.7 \%$ & $4.9 \%$ & $5.7 \%$ & $1.6 \%$ & $5.1 \%$ & 3.219 & $12.3 \%$ & $41.2 \%$ \\
\hline EUROPE & $11.9 \%$ & $37.0 \%$ & $33.3 \%$ & $4.1 \%$ & $7.0 \%$ & 1.717 & $17.9 \%$ & $31.7 \%$ \\
\hline Eastern Europe & $5.0 \%$ & $8.1 \%$ & $7.9 \%$ & $2.2 \%$ & $4.3 \%$ & 1.930 & $17.4 \%$ & $34.2 \%$ \\
\hline Rest of Europe & $6.9 \%$ & $28.9 \%$ & $25.4 \%$ & $5.2 \%$ & $8.6 \%$ & 1.637 & $18.3 \%$ & $31.0 \%$ \\
\hline incl. EU15 & $6.2 \%$ & $23.8 \%$ & $21.9 \%$ & $4.8 \%$ & $8.1 \%$ & 1.685 & $18.6 \%$ & $32.5 \%$ \\
\hline incl. EU25 & $7.4 \%$ & $28.5 \%$ & $26.5 \%$ & $4.9 \%$ & $8.7 \%$ & 1.789 & $17.6 \%$ & $32.8 \%$ \\
\hline AFRICA & $13.1 \%$ & $7.9 \%$ & $6.9 \%$ & $1.5 \%$ & $10.4 \%$ & 7.031 & $4.0 \%$ & $30.9 \%$ \\
\hline Northern Africa & $2.8 \%$ & $4.0 \%$ & $2.2 \%$ & $2.9 \%$ & $7.3 \%$ & 2.489 & $7.5 \%$ & $19.6 \%$ \\
\hline Sub-Saharan Africa & $10.3 \%$ & $3.9 \%$ & $4.7 \%$ & $1.0 \%$ & $13.1 \%$ & 13.287 & $2.8 \%$ & $42.5 \%$ \\
\hline ASIA & $60.8 \%$ & $26.4 \%$ & $35.1 \%$ & $0.8 \%$ & $5.5 \%$ & 7.123 & $6.3 \%$ & $46.8 \%$ \\
\hline Eastern Asia & $24.7 \%$ & $7.3 \%$ & $11.5 \%$ & $0.5 \%$ & $3.9 \%$ & 8.544 & $6.3 \%$ & $55.5 \%$ \\
\hline South-central Asia & $24.4 \%$ & $6.3 \%$ & $9.3 \%$ & $0.5 \%$ & $5.3 \%$ & 10.030 & $5.0 \%$ & $52.5 \%$ \\
\hline South-eastern Asia & $8.5 \%$ & $7.3 \%$ & $10.6 \%$ & $1.6 \%$ & $9.8 \%$ & 5.980 & $7.9 \%$ & $51.4 \%$ \\
\hline Near and Middle East & $3.2 \%$ & $5.5 \%$ & $3.6 \%$ & $3.5 \%$ & $6.9 \%$ & 1.937 & $11.4 \%$ & $22.9 \%$ \\
\hline OCEANIA & $0.5 \%$ & $1.4 \%$ & $1.8 \%$ & $4.3 \%$ & $6.8 \%$ & 1.578 & $27.8 \%$ & $45.0 \%$ \\
\hline Australia and New Zealand & $0.4 \%$ & $1.0 \%$ & $1.4 \%$ & $3.7 \%$ & $5.4 \%$ & 1.479 & $32.7 \%$ & $49.2 \%$ \\
\hline Other Pacific countries & $0.1 \%$ & $0.4 \%$ & $0.4 \%$ & $7.6 \%$ & $48.7 \%$ & 6.391 & $3.1 \%$ & $35.2 \%$ \\
\hline
\end{tabular}

Other Pacific countries 


\begin{tabular}{|c|c|c|c|c|c|}
\hline \multicolumn{6}{|c|}{$\begin{array}{l}\text { Table } 2 \text { : Estimation results : benchmark regressions } \\
\text { Dependent variable=gross investment in human capital. }\end{array}$} \\
\hline Variable & (1) & (2) & (3) & (4) & (5) \\
\hline \multirow[t]{2}{*}{ constant } & -0.0035 & -0.0798 & - & 0.0214 & -0.0798 \\
\hline & {$[-0.04]$} & {$[-1.12]$} & - & {$[0.20]$} & {$[-1.12]$} \\
\hline \multirow[t]{2}{*}{$\ln (p 90)$} & $0.0487^{*}$ & $0.0421^{* *}$ & $0.0481^{* *}$ & $0.0573 * *$ & $0.0499 * *$ \\
\hline & [1.86] & [2.03] & [2.29] & [2.22] & [2.30] \\
\hline \multirow[t]{2}{*}{$\ln (H 90)$} & $-0.2240 * * *$ & $-0.2211 * * *$ & $-0.1990 * * *$ & $-0.2238 * * *$ & $-0.2216^{* * *}$ \\
\hline & {$[-6.37]$} & {$[-6.30]$} & {$[-9.12]$} & {$[-6.38]$} & [-6.37] \\
\hline \multirow[t]{2}{*}{$S S A D$} & $-0.382 * * *$ & $-0.325^{* * *}$ & $-0.299 * * *$ & $-0.386^{* * *}$ & $-0.323 * * *$ \\
\hline & [-3.98] & {$[-3.91]$} & {$[-4.36]$} & [-4.13] & {$[-3.90]$} \\
\hline \multirow[t]{2}{*}{$L A T D$} & 0.0258 & - & - & -0.0351 & - \\
\hline & {$[-0.45]$} & - & - & {$[-0.59]$} & - \\
\hline \multirow[t]{2}{*}{ DENS90 } & -0.0998 & - & - & -0.1085 & - \\
\hline & {$[-0.92]$} & - & - & {$[-0.99]$} & - \\
\hline \multirow[t]{2}{*}{ RM90 } & -0.0051 & - & - & -0.0053 & - \\
\hline & {$[-1.12]$} & - & - & {$[-1.14]$} & - \\
\hline$R^{2}$ & 0.410 & 0.353 & 0.763 & 0.409 & 0.352 \\
\hline Hausman & - & - & - & 0.552 & 0.484 \\
\hline$J$ test & - & - & - & 0.056 & 0.163 \\
\hline Nobs & 103 & 127 & 127 & 103 & 127 \\
\hline
\end{tabular}

$\underline{\text { Notes }}$

a) Between brackets, T-statistics. White Corrections for heteroscedasticity.

b) Columns 1, 2 and 3: OLS regressions. Columns 4 and 5 : variable instrumental regressions; instruments: populatition size and stock of migrants in OECD countries.

c) Hausman and $J$ test report the p-values for respectively the null of no endogeneity of migration rates and the null of valid instruments (no correlation with error term).

$*, * *$ and $* * *$ denote significance at respectively 10,5 and $1 \%$ levels. 


\begin{tabular}{lccc}
\hline \hline Table 3 : Estimation results : conditional effects & & \\
Dependent variable=gross investment in human capital. & & $(3)$ \\
\hline \hline Variable & $(1)$ & $(2)$ & -0.100 \\
\hline constant & $-0.128^{*}$ & -0.089 & {$[-1.33]$} \\
& {$[-1.69]$} & {$[-1.08]$} & $0.036^{* *}$ \\
$\ln (p 90)$ & $0.031^{*}$ & $0.040^{* *}$ & {$[2.53]$} \\
& {$[1.86]$} & {$[2.74]$} & 0.012 \\
$\ln (p 90) . G N I D$ & 0.037 & 0.005 & {$[0.47]$} \\
& {$[1.09]$} & {$[0.17]$} & $-0.228^{* * *}$ \\
$\ln (H 90)$ & $-0.237^{* * *}$ & $-0.224^{* * *}$ & {$[-5.83]$} \\
& {$[-6.08]$} & {$[-5.34]$} & $-0.326^{* * *}$ \\
SSAD & $-0.322^{* * *}$ & $-0.327^{* * *}$ & {$[-3.95]$} \\
\hline$R^{2}$ & {$[-3.93]$} & {$[-3.96]$} & 0.355 \\
Nobs & 0.370 & 0.353 & 127 \\
\hline \hline
\end{tabular}

Notes

a) Between brackets, T-statistics. White Corrections for heteroscedasticity.

b) In columns (1) (2) and (3), the low income dummies are defined using

thresholds of income per head in 1990 equal respecitively to 500, 750 and 900 USD.

$*, * *$ and $* * *$ denote significance at respectively 10,5 and $1 \%$ levels. 


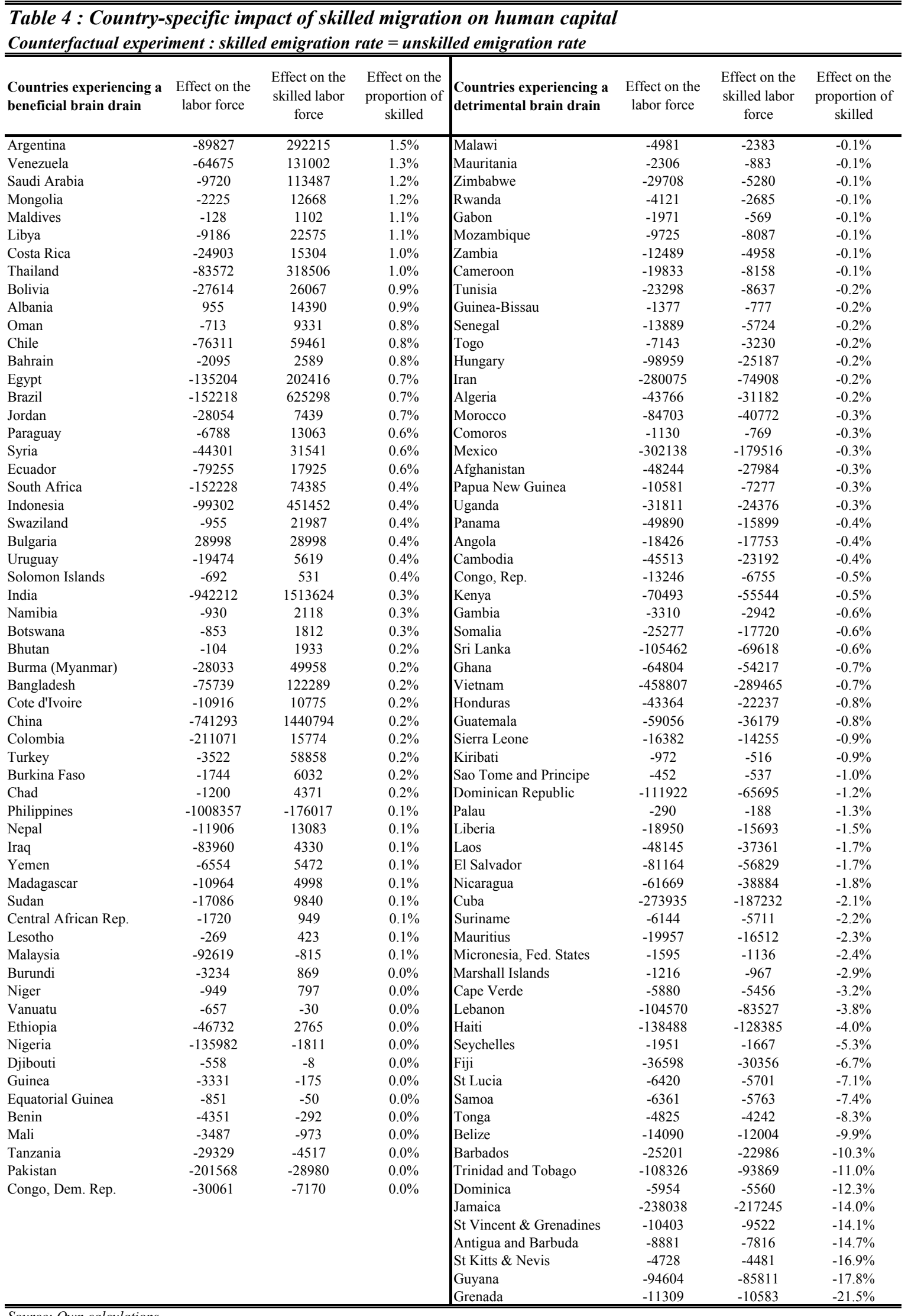


Figure 1 - Brain drain effect and skilled migration rate

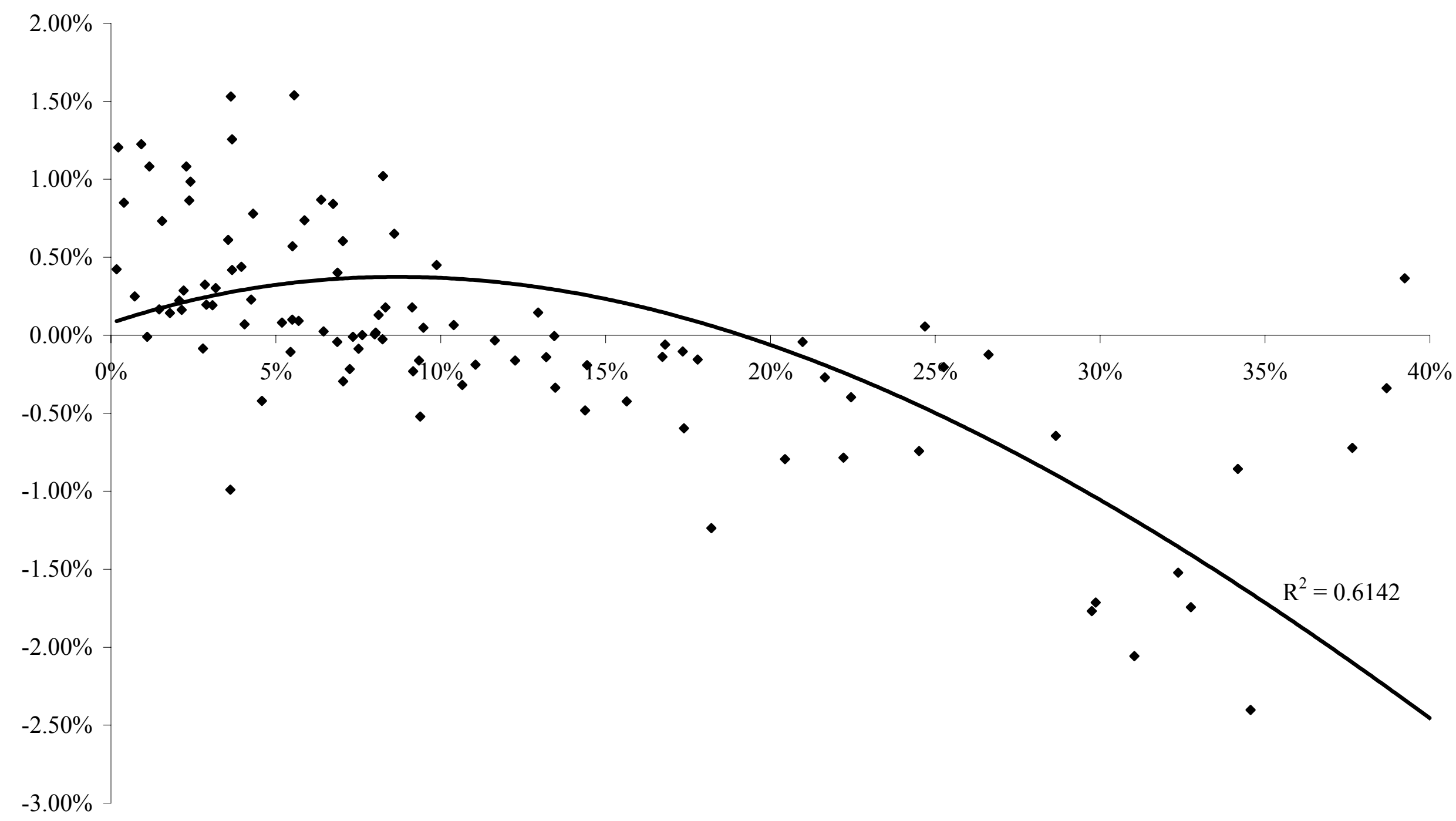


Figure 2 - Brain drain effect and residents' human capital

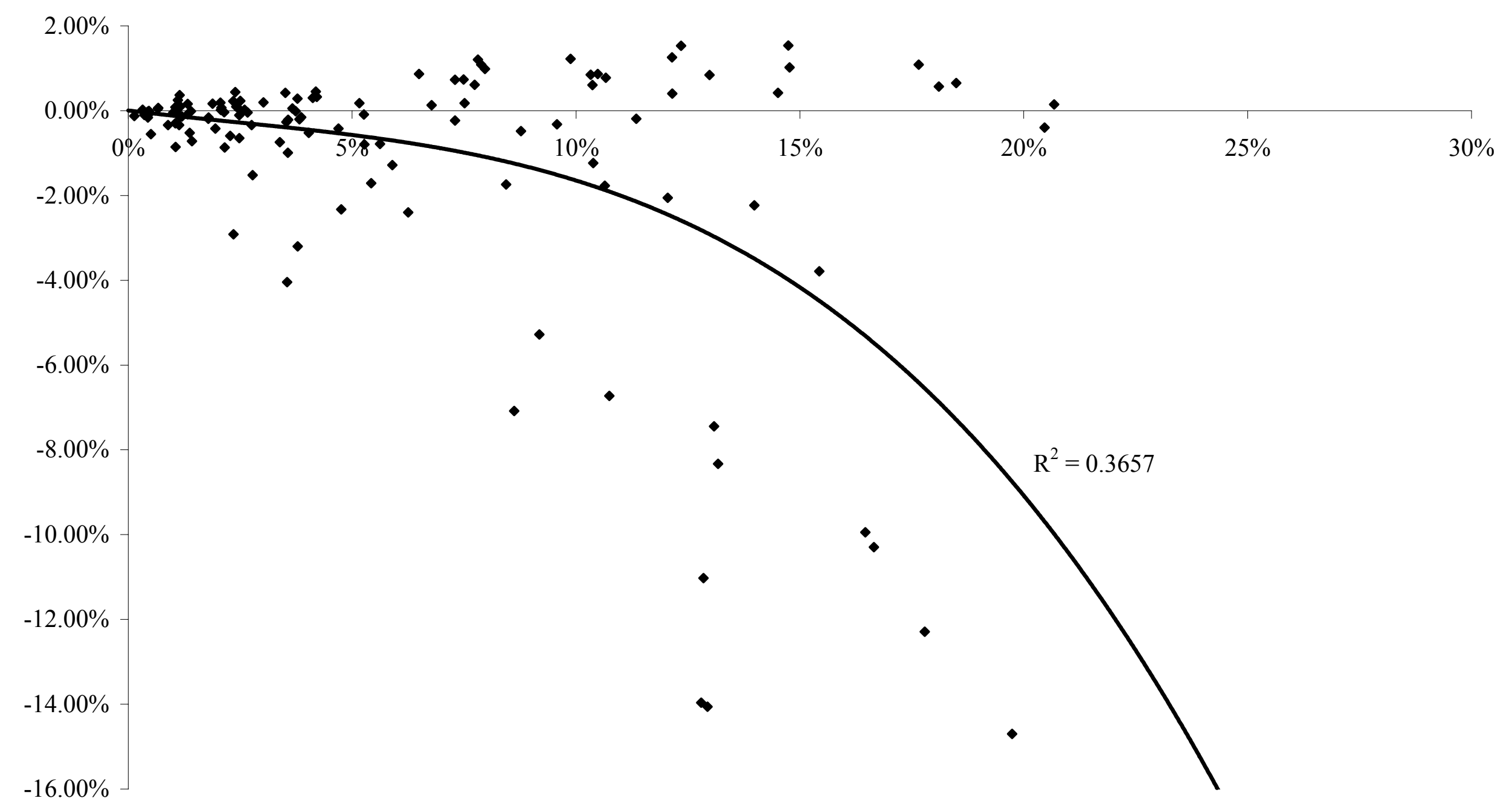


Table 5 : Results by country group

Counterfactual experiment $:$ skilled emigration rate $=$ unskilled emigration rate

\begin{tabular}{|c|c|c|c|c|c|c|c|c|c|}
\hline & \multicolumn{3}{|c|}{ Observations in 2000} & \multicolumn{3}{|c|}{ Counterfactual experiment } & \multicolumn{3}{|c|}{ Brain drain effect } \\
\hline & $\begin{array}{c}\text { Labor Force } \\
\text { (LFx1000) }\end{array}$ & $\begin{array}{l}\text { Number of skilled } \\
\text { workers (Yx1000) }\end{array}$ & $\begin{array}{l}\text { In \% of the labor } \\
\text { force }(y=Y / L F)\end{array}$ & $\begin{array}{l}\text { Labor Force } \\
\text { (LF'x1000) }\end{array}$ & $\begin{array}{c}\text { Number of skilled } \\
\text { workers } \\
\text { (Y'x1000) }\end{array}$ & $\begin{array}{l}\text { In \% of the labor } \\
\text { force }\left(y^{\prime}=Y^{\prime} / L F^{\prime}\right)\end{array}$ & $\begin{array}{c}\text { Change in the } \\
\text { number of skilled } \\
\left(Y-Y^{\prime}\right)\end{array}$ & $\begin{array}{c}\text { Change in \% of } \\
\left(Y^{\prime}\right)\end{array}$ & $\begin{array}{l}\text { Change in the } \\
\text { proportion of } \\
\text { skilled }\left(y-y^{\prime}\right)\end{array}$ \\
\hline \multicolumn{10}{|l|}{ By country size (in 2000) } \\
\hline Large (>25 million) & 2001110 & 97370 & $4.9 \%$ & 2006533 & 93081 & $4.6 \%$ & 4288 & $4.6 \%$ & $0.2 \%$ \\
\hline Upper-Middle (from 10 to 25 ) & 181152 & 11968 & $6.6 \%$ & 182472 & 12066 & $6.6 \%$ & -97 & $-0.8 \%$ & $0.0 \%$ \\
\hline Lower-Middle (from 2.5 to 10 ) & 80638 & 6525 & $8.1 \%$ & 81752 & 7104 & $8.7 \%$ & -578 & $-8.1 \%$ & $-0.6 \%$ \\
\hline Small (<2.5 million) & 10026 & 632 & $6.3 \%$ & 10419 & 946 & $9.1 \%$ & -313 & $-33.1 \%$ & $-2.8 \%$ \\
\hline \multicolumn{10}{|l|}{ By Income Group (in 2000) } \\
\hline Upper-Middle & 244175 & 26917 & $11.0 \%$ & 245441 & 26064 & $10.6 \%$ & 853 & $3.3 \%$ & $0.4 \%$ \\
\hline Lower-Middle & 274867 & 29990 & $10.9 \%$ & 278272 & 30356 & $10.9 \%$ & -367 & $-1.2 \%$ & $0.0 \%$ \\
\hline Low-Income & 1753884 & 59589 & $3.4 \%$ & 1757464 & 56776 & $3.2 \%$ & 2813 & $5.0 \%$ & $0.2 \%$ \\
\hline Least Developed & 278320 & 6801 & $2.4 \%$ & 279192 & 6939 & $2.5 \%$ & -137 & $-2.0 \%$ & $0.0 \%$ \\
\hline \multicolumn{10}{|l|}{ By region } \\
\hline China & 759550 & 20508 & $2.7 \%$ & 760291 & 19067 & $2.5 \%$ & 1441 & $7.6 \%$ & $0.2 \%$ \\
\hline India & 480422 & 23060 & $4.8 \%$ & 481364 & 21547 & $4.5 \%$ & 1514 & $7.0 \%$ & $0.3 \%$ \\
\hline Indonesia & 103980 & 5199 & $5.0 \%$ & 104079 & 4748 & $4.6 \%$ & 451 & $9.5 \%$ & $0.4 \%$ \\
\hline Turkey & 33130 & 2816 & $8.5 \%$ & 33134 & 2757 & $8.3 \%$ & 59 & $2.1 \%$ & $0.2 \%$ \\
\hline Other Middle East & 62404 & 5494 & $8.8 \%$ & 62964 & 5478 & $8.7 \%$ & 16 & $0.3 \%$ & $0.1 \%$ \\
\hline Other Asia & 344538 & 23927 & $6.9 \%$ & 347308 & 24045 & $6.9 \%$ & -118 & $-0.5 \%$ & $0.0 \%$ \\
\hline ASIA & 1721620 & 75510 & $4.4 \%$ & 1726177 & 72163 & $4.2 \%$ & 3347 & $4.6 \%$ & $0.2 \%$ \\
\hline Egypt & 29266 & 3131 & $10.7 \%$ & 29401 & 2929 & $10.0 \%$ & 202 & $6.9 \%$ & $0.7 \%$ \\
\hline Other Northern Africa & 33560 & 2264 & $6.7 \%$ & 33722 & 2322 & $6.9 \%$ & -58 & $-2.5 \%$ & $-0.1 \%$ \\
\hline Nigeria & 40174 & 1245 & $3.1 \%$ & 40310 & 1247 & $3.1 \%$ & -2 & $-0.1 \%$ & $0.0 \%$ \\
\hline South Africa & 19914 & 2071 & $10.4 \%$ & 20066 & 1997 & $10.0 \%$ & 74 & $3.7 \%$ & $0.4 \%$ \\
\hline Other Sub-Sahara Africa & 174178 & 3164 & $1.8 \%$ & 174747 & 3387 & $1.9 \%$ & -222 & $-6.6 \%$ & $-0.1 \%$ \\
\hline Sub-Saharan Africa & 234266 & 6480 & $2.8 \%$ & 235123 & 6630 & $2.8 \%$ & -150 & $-2.3 \%$ & $-0.1 \%$ \\
\hline AFRICA & 296842 & 11870 & $4.0 \%$ & 297995 & 11876 & $4.0 \%$ & -5 & $0.0 \%$ & $0.0 \%$ \\
\hline PACIFIC ISLANDS & 849 & 60 & $7.1 \%$ & 903 & 103 & $11.4 \%$ & -43 & $-41.4 \%$ & $-4.3 \%$ \\
\hline Mexico & 45226 & 5111 & $11.3 \%$ & 45528 & 5290 & $11.6 \%$ & -180 & $-3.4 \%$ & $-0.3 \%$ \\
\hline Carribbean & 16577 & 1545 & $9.3 \%$ & 17520 & 2304 & $13.1 \%$ & -759 & $-32.9 \%$ & $-3.8 \%$ \\
\hline Other Central America & 14499 & 1498 & $10.3 \%$ & 14833 & 1665 & $11.2 \%$ & -167 & $-10.0 \%$ & $-0.9 \%$ \\
\hline Central America & 76302 & 8154 & $10.7 \%$ & 77882 & 9259 & $11.9 \%$ & -1105 & $-11.9 \%$ & $-1.2 \%$ \\
\hline Brazil & 87063 & 7313 & $8.4 \%$ & 87215 & 6688 & $7.7 \%$ & 625 & $9.3 \%$ & $0.7 \%$ \\
\hline Argentina & 20151 & 3970 & $19.7 \%$ & 20241 & 3678 & $18.2 \%$ & 292 & $7.9 \%$ & $1.5 \%$ \\
\hline Other South-America & 53887 & 7410 & $13.8 \%$ & 54473 & 7232 & $13.3 \%$ & 177 & $2.5 \%$ & $0.5 \%$ \\
\hline South America & 161101 & 18693 & $11.6 \%$ & 161929 & 17598 & $10.9 \%$ & 1095 & $6.2 \%$ & $0.7 \%$ \\
\hline LATIN AMERICA & 237403 & 26846 & $11.3 \%$ & 239811 & 26856 & $11.2 \%$ & -10 & $0.0 \%$ & $0.1 \%$ \\
\hline TOTAL & 2272926 & 116495 & $5.1 \%$ & 2281177 & 113196 & $5.0 \%$ & 3299 & $2.9 \%$ & $0.2 \%$ \\
\hline
\end{tabular}

Source: Own calculations 
Département des Sciences Économiques de l'Université catholique de Louvain

Institut de Recherches Économiques et Sociales

Place Montesquieu, 3

1348 Louvain-la-Neuve, Belgique 